\title{
Anthropological Risks of the Information Society
}

\section{Olga Borisovna Skorodumova}

Department of Philosophy, The Russian State social University, Moscow, Russia, 307 Apartment, 37/21, Marshal Tukhachevsky st., Moscow, 123154, Russia

\section{Liliya Fedorovna Matronina}

Department of Philosophy, Sociology and Political Science, Moscow State Technical University of Radio Engineering, Electronics and Automation, Moscow, Russia

\section{Tatiana Ivanovna Koval}

Department of Philosophy, The Russian State social University, Moscow, Russia

Doi:10.5901/mjss.2015.v6n3s3p295

\begin{abstract}
The paper presents the research results of the problem of information society risk exposure in an anthropological aspect. The authors reveal new conditions of human existence in the context of both positive and negative components based on the analysis of modernization processes taking place in information epoch and their impact on the human. Potential dangers to human personality and possible ways of their destructive influence, relating to identity and trust loss, increase in hyperdynamism, are studied. When considering the production of risks by the example of modern biomedical technologies, the authors conclude that development and application of modern convergent means of socium and human transformation provoke large-scale risks and threat to the future of mankind. It results in the need for adequate humanitarian understanding of existent processes and development of new strategic approaches to the risk exposure problem solution. The specific nature of educational activity under the conditions of establishing new stage of information society development - the knowledge society is exposed. Risks of wide-spread technologic approach to education quality management are distinguished. Possible risk management methods in information society by the example of education quality management are proposed. The issue is the need for education management holistic model formation in the unity of technologic and axiological approaches. Philosophical and theoretical analysis of anthropological risks of the information society allowed stating a number of proposals and recommendations of practical nature, which can be used by organizations/corporations that make decisions in the area of risk management.
\end{abstract}

Keywords: information society, anthropological risk, risk exposure, identity, creativity, hyperdynamism, principle of trust, transhumanism, convergent technologies, education, education quality management.

\section{Introduction}

Development of the information society and formation of its new stage - the knowledge society (Towards Knowledge Societies, 2005) keeps current the need in the analysis of contradictions related to intensive development of new information technologies, processes of modernization and their revolutionary impact on each sphere of social life. The intensity of changes in economic field and formation of "the knowledge economy" directly influence dynamics of socium in general. Complexity of economic and social systems rises sharply leading to the complexity level of highly-organized systems in wild life. Supercomplexity gives rise to synergetic effects relating to systems' instability that leads to inconsistency and uncertainty of existence of human and society in the modern epoch. When analyzing the nature of the information society, researchers consider risk exposure its base characteristic (Beck U., 2009; Lewens T., 2007; Rosa E., \& McCright A., 2014; Bechmann G., 2010). The reason for addressing the notion of "risk" is largely conditioned by increase in complexity of modern social structures, decrease in their manageability level, and principal uncontrollability in many cases: the human is made to make decisions under conditions of uncertainty. In the framework of industrialism the idea of rational human, who strives in his economic activity for maximum profit, looks for ways of expenditure minimization, rationally builds relations with surrounding persons, has developed. Emergence of modern information infrastructure causes saturation of information flows, where it's difficult to orientate oneself, escalating competition, 
extremely short life of the product, which is succeeded by a new product, etc. It promotes demand for innovations, which, on the one hand, are based on market/business demands, and, on the other hand, on creative urge, insight than good judgment. Commitment to innovations and, consequently, the need for development of "preventive strategies" (Bechmann, 2010), which are perceived as risk ones, because they give rise to uncertainty and unreliability, cause the intense interest to the notion of risk.

Taking into account the diversity of approaches to identification of risk essence, its main aspects can be distinguished: 1) risk involves one or another degree of uncertainty, depends on accidental events; 2) a risk situation features the moment of alternative decisions making: to risk or not to risk; 3) risks involves its probabilistic measurement, where it's possible to forecast the degree of possibility of expected results; 4) risk is dialectical by its nature, it includes probability of negative phenomenon, and secondary positive results at the same time. In general, risk is defined by a set of internal and external factors. It is driven by both activity of people, who make alternative decisions and calculate degrees of their outcomes possibility, and general socioeconomical and sociocultural situation (Skorodumova, O. B. et al., 2014).

The studies of risks are carried out by scientists in many trends. N. Frank's Risk Uncertainty and Profit published in 1932 became a classical work that presents the in-depth analysis of risk essence (Knight, 2014, reprint of 1921). According to his views, risk is considered s situation, which cannot be neither measured not calculated ("Knightian uncertainty"). Switch from the industrial society to the information one intensified researches of risks subject matter. Problematics related to economical (Renn O., 2008), religious (Barannikov V. P., \& Matronina L. F., 2004), ecological (Joffe H., et al., 2013), information (Skorodumova O. B., et al., 2015) risks appears to be most developed in academic literature. Considerable interest was shown in risk research in the area of mass media (Brake D., 2014) due to spreading open electronic (online) systems and intensification of cyber wars. At the same time, anthropologic risks are underresearched.

Development of the information society and its transformation into the knowledge society place certain requirements to strategies of anthropological status Homo Sapiens preservation, creation of conditions for human adaptation to avalanche information flow, that causes new risks related to education system, loss of abilities to cultural identification, crisis of confidence at all levels of social life. The papers' authors analyze anthropological risks with regard to increase in their variety due to enhancing modern high-end technologies. UNESCO world report Towards Knowledge Societies (Towards Knowledge Societies, 2005) states that threats created by the modern society "approach" the human closer and closer, and can be revealed, i.a. in bioapproaches. Thus, formerly scientific technologies in the area of biomedicine provoking certain moral contradictions largely widened opportunities of human rights for health and secured life, now newest convergent technologies caused the actual technobiologocal evolution of Homo Sapiens as Technology and Society: Building Our Sociotechnical Future's authors note (Johnson D. G. \& Wetmore J. M., 2009). At the turn of the $20^{\text {th }}$ century the estimates of human biological evolution prospects changed. This evolution is related to bio-, nano-, information and cognitive technologies, abbreviated BNIC (Ball P., 2006; Grunwald A., 2012). At the same time, under the conditions of the shift to the knowledge society the traditional (classical) system of education undergoes significant transformation. The modern education increasingly comes down to teaching and is focused to formation of competences - qualities that correspond to the market economy (Towards Knowledge Societies, 2005). This phenomenon is promoted by the established in the globalizing world technologic access to education quality management, the base of which is the concept of Total Quality Management (Sallis E., 2002; Mukhopadhyay, 2005; Okechukwu F. Ch., 2011; Padhi N., 2010).

Considering the level of problem research, the paper's authors focus attention on examination of anthropological risks emerging in the information society. Contradictions of the knowledge society as most developed stage of the information society are exposed. The dialectic of the modern age needs in the contradictory unity of innovation opportunities, provided by information environment and its threats to human personality, is considered. The analysis of human development prospects in the context of biotechnological intervention into human nature is provided. The special role of education quality increase in personality's values formation is stated.

\section{Methods and Results}

The research was carried out based on methods common to social philosophical analysis. Hermeneutics tradition methodology was applied to clarify base notions. Dynamics of information society development was carried out based on dialectical approach that involves detecting contradictory aspects of the modern socium and its integrity analysis. Comparative analysis was applied when comparing different stages of modern society development. The use of this method allowed observing dynamics and deepening of emerging risks, for example, in the area 0 biomedical technologies. The authors needed system approach for wider coverage of scientific and technical development 
consequences and for the purpose of estimation of these consequences, prospects, corresponding actions and recommendations. The elements of system approach gave an opportunity to examine risk as an emergent factor of socium.

Carried out study showed that the information society development at its modern stage called the knowledge society is of contradictory nature related to objective needs of this society development and anthropological risks, which appear in this respect. It's shown that the most significant needs of the person of the information epoch are selfidentification need, trust, new knowledge and corresponding kinds of creative activity. Realization of these needs gives rise to specific risks: loss of identification, hyperactivity, and trust, which are determining for the modern stage of information society development. Based on the study of actual practical results regarding biomedical technologies and scientific researches implementation in this area scientific technological prerequisites of modern anthropological risks related to wide spreading biomedical technologies are defined. Wide spread in modern society risks of technologic approach to education management are exposed. Possible ways of risk management in the information society by the example of education quality management are suggested. Philosophical and theoretical analysis of anthropological risks of the information society carried out by the authors allowed them to state a number of proposals and recommendations of practical nature, which can be used when developing strategies of society's risk exposure decrease, decision-making in the area of management in the framework of long-term international, federal, and regional target programs.

\section{Discussion}

Anthropological risks as a social phenomenon are closely related to information society's features, its culture and are determined by active development of virtual environment and innovations intensity. Formation of a new informationcommunication virtual media leads to a number of anthropological risks.

Firstly, it's identity loss risk. The principle of transformation involving heavy increase in diversity and variation becomes an organizing principle of person's cultural life in the information society. Dialogue of cultures is deeply intensified (Melikov I. M. \& Gezalov A.A, 2012). Play activity penetrates all spheres of social life. The more liberated psyche is, the more it's considered effective. Psyche released from traditional prohibitions gives an opportunity to unlock itself in the most incredible way. A new type of consciousness appears, where lightning flash-like intuitive insights entwine with mind's guesses. Science includes the elements of religious world-view, religion uses science data, sophisticated culture peacefully co-exists with mass one. Reality construction becomes the foundational property of the human. "The new human" looses his stem. So-called the Proteus' phenomenon takes place, when life turns into the kaleidoscope of images, set of roles, produced by person's consciousness under the influence of mass media. The person is caught in front of his TV or computer in a flash, and usually cannot stand against socially engaged information flow. Contradictory essence of anthropologic risk of identity loss is that, on the one hand, human personality becomes diversified, opportunity of choice and creative experiments expands, on the other hand, link to the real world becomes weaker, idea of one's own status, goals and meaning of life blurs. Finding himself in the framework of new structure, new dependence, the human has to pay the highest price - inconsiderate denial of himself.

At the beginning of the $21^{\text {th }}$ century focus in the analysis of social realias of the information society shifted to knowledge as a specific type of information. The task of distinguishing in information flow most significant, ordered valueoriented data, which the human can use to exercise effective actions, becomes relevant (Skorodumova O.B. et al., 2015). Under new conditions knowledge specific character is determined by constant dynamics of knowledge acquisition process. Standards, requirements are being changed; base information obtained in the framework of professional and higher education rapidly becomes obsolete. In order to be successful in the modern world it's necessary to timely update knowledge at hand and types of activities. In this respect specific risks emerge. They can be called anthropological risks of hyperactivity. Such risks involve specialist's constant changes of activity profile in order to be in-demand: cut-throat competition requires for quick, original decisions. Critical need in innovative initiatives increases significance of sensitive response to today's demands. Consequently, one of the most important problems is development of individual's special qualities related to continuous retraining and kind of "reprogramming" depending on the changing needs of extensively developing business environment. In the modern world it's quite difficult to define what fragment of available knowledge will be necessary to the specialist to solve one or another non-standard problem. In the search for compensation considerable arrays of information are drawn. Knowledge looses consistency and integrity, frequently turning into a mosaic set of separate fragments providing some or other edges of activities. Anthropologic risk of hyperactivity is essentially contradictory. On the one hand, the human is given an opportunity of wide choice of non-standard creative decisions: the intellectual is succeeded by the creative class, which becomes the key factor of successful economical development of the knowledge society. Creativity in its diversified manifestations increasingly spread in various types of 
activity (Florida R., 2002). However, on the other hand, expansion of information saturation of the human, i.a. at the level of knowledge, cannot be limitless. There are biological limits of information perception, its processing and application in activity. Constant change of activity gives rise to fatigue, depression, which are tried to escape by retreat to new, as a rule, play types of activities. It only aggravates the case. Such hyperactivity leads to serious consequences up to mental disorders.

Contradictory nature of information society development leads to the anthropological risk of loss of trust. The knowledge society is a dynamically developing structure, for which, above all things, comprehension of knowledge role as a success factor in any field of activities is specific. Increase in knowledge status in society, its expansion leads to the need in new knowledge that gives rise to the paradox of continuous shortage of knowledge. In the information society innovation and principle of trust become driving force for its development. It's clearly traced on the example of the realization conditions of "business on demand", which can yield significant economic effect. One of base ideas of this strategy is possibility of information services and technologies lease. Emergent opportunity of financial flows and accounting records management on the part of lessor's center is acceptable if there's confidence in honesty and transparency of lessor's intentions. Information security problem solution is also impossible without applying the principle of trust (Skorodumova O.B., 2004). The contradiction of the anthropological risk of loss of trust is that the need in trust for successful operation of the information society is closely related to growth in distrust in all spheres of life. There's increase in distrust at the level of social networks, which demonstrate opposition spirits in relation to ruling authorities. Recently the tendency towards information isolationism is observed not only on the part of the East, particularly, China that implemented the Golden Shield Project that limits free access to resources of the Internet for Chinese population, but on the part of USA, EU, Russia, which confirmed possibility of control of the Internet at legislative level.

Increase in anthropological risk directly relates to the fact that the human becomes an object of scientific and technological researches (Yudin B.G, 2008; Lektorsky V.A., 2010). Biomedical technologies started their rampant development in the last quarter of the $20^{\text {th }}$ century and nowadays have extended technological capabilities of control and interference into the natural processes of birth, flow and end of human life, that sometimes create serious threats to his health and existence. According to a number of leading Russian scientists (Yudin B.G. \& Kapitsa S.P, 2005; Lektorsky V.A., 2010), methods of lesional tissues and organs replacement, euthanasia procedures, active influencing active ageing process - evidence for medical technologies transformation into management facilities of human life and creating new criteria of life and death.

More than 10 years ago a work of one of leading German philosophers J. Habermas J. Future of Humanity (Habermas J., 2002) was published. It is concerned with threats emanating from new opportunities of biotechnologies. In the course of this time biotechnologies managed to gain a footing and currency, while corresponding risks, Habermas stated, become increasingly sharp, since urgency of ethical accounts diminished in the modern society for the benefit of business calculations of profits and losses. Modern human reproduction methods extensively applied in the world since 1978 result in both the opportunity to experience the joy of parenthood by spouses, who cannot have children due to medical conditions, and risk of surrogacy transformation into an obnoxious kind of business and depreciation of family values: a woman carrying a child should disaffect her feeling to him or her in order to meet her contractual obligations and give the child into customer's hands. Moreover, such technologies use provides the child with several parents (or even pairs of parents!), that undermines conventional basis of traditional family relations. An important world outlook problem appears in regard to actively used (for today on animals) cloning technology: this technology needs only one somatic cell of an organism of one gender, consequently, another gender may become biologically excessive.

Development of gene engineering and therapy, completion of human genome mapping at the end of the $20^{\text {th }}$ century made it possible to detect and eliminate serious genetic deviations at embryonal stage. However, according to researchers (Stock G., 2003), there are also dangers. The issue is mainly about the projects of radical rebuilding of the human, supposedly his genotype improvement, that indicates perception of the person as a thing, properties of which can be changed subject to somebody's ideas of perfection and someone's unveiled desire to assign the Creator' role. Since the ethic problem involves impossibility of drawing the clear boundary between what the majority of people consider the good, i.e. therapeutic action, and what the danger of excessive use conceals, i.e. "improvement", many scientists caution the research community and society of excessive devotion to such procedures (Bouchard R., 2003; Bronzino J., 2006).

The modern scientific and technical development promoted the greater number of opportunities to improve person's life using scientific and technological achievements, release from ageing and even death, extension of human body potential, increase in intellectual and psychological capabilities. Transhumanism followers are confident that the modern human is a step in establishing a new kind, formation of which will take place not subject to biological laws, but achievements of science and technology. This movement's representatives, who are specialists in various fields of knowledge, assume that by the means of gene engineering, information and nanotechnologies achievements, affecting 
human genic and nervous system and replacing a number of organs with artificial ones, it's possible to increase duration of human life and make it immortal in the future. Tasks for the next decades are creation of artificial intelligence able as a human one to experience emotions, reproduction of wild life systems (several years ago the first fully functioning and reproducing artificial cell controlled by artificial DNA was created), biological processes management at molecular level, disclosing cerebration secrets and human consciousness management. Thus, new convergent technologies pose a question about new understanding of human essence and nature. Considering striking changes taking place in society, Fukuyama F. (Fukuyama F., 2004) coined the term of "posthumanism". Other researchers (Yudin B.G, 2008; Kudashov V. I. \& Omelchenko N. V, 2014; Pride V. \& Korotaev A.V, 2008), defining reality as technobioevolution, state that the human doesn't cease to be a human being, but becomes more and more technologized. They don't identify the technohuman with neither the posthuman not biorobot, but consider a stage of homo sapiens development technologized homo sapiens.

BNIC model of European variant features development of economical, educational, managerial and legal aspects, that makes it too technocratic. Russian scientists (Kovalchuk M.V., 2011) associate the modern stage of convergent development with involvement of social and humanity sciences and corresponding change of BNIC into BNICS, where "S" means "social and humanity technologies". Social and humanity component will allow integratively complementing the existing model with social, anthropological and philosophical images. The specific nature of the risks of technical intervention into human body, threat of their inconvertibility imposes the need in formation of social attitude to modern technologies. Due to interdisciplinarity of convergent technologies, the condition of corresponding risks minimization presents establishing interdisciplinary methodology with obligatory involvement of humane technologies, which will allow keeping pace with scientific and technological possibilities implementation in our life, carrying out their estimation in due time and, if necessary, developing precautionary measures not only for the human personality but society in general.

***

Really and truly, the art to make decisions and settle suspicions and difficulties is a key to all problems" (Gui Gu Tzu, an ancient Chinese treatise). When bringing anthropological risks of the information society under deliberation, it's necessary to look for ways of emerging problems solution. Task complexity is that this choice is carried our under conditions of uncertainty, and, consequently under conditions of risk. Even today we have to make decisions the future depends on; decisions wherein neither positive nor negative consequences can be covered or managed.

Under present circumstances value of education, which should be focused on integral personality formation, increases. A person of the knowledge society is not just a person, who has certain body of knowledge, but, foremost, a person, who knows the methodology of the search for the new, the skill to apply his knowledge in his life activity. The knowledge society places new requirements for a person, who should be able to easily orient himself in information flow, develop cognitive abilities and critical mind, create new significant forms, to use obtained knowledge in practice, to choose adequate ways and methods of problem solution, to find necessary information, to establish communication contacts and relations, and to work in team. Wide spread in the modern world competency-based approach to education is focused on this issues solution. In many economically developed countries competences are considered a complex indicator for describing education results. The problem of education quality becomes actual.

Education quality management becomes the modern paradigm of education management (Matronina L. F., 2014). At the turn of the $20^{\text {th }}$ century the systems of quality management based on the concept of Total Quality Management (TQM) are introduced in educational institutions in many countries of the world (including Russia) (Sallis E., 2002). TQM provides goal-oriented planned application of systems and methods of quality management with the participation of management and all levels of employees and rational use of technical capabilities. In TQM a special part is assigned to the procedures of performance measurement, owing to which it's possible to detect processes effectiveness and quality improvement. A specialist in the area of quality management Sallis E. (Sallis, 2002) gives a high rating to this concept, but states that TQM won't yield immediate fruits and it's not a panacea against all problems education face. It's rather a set of tools, which can be used in educational institutions management. The main advantage of TQM is this focus on continuous improvement. An important condition for necessary result achievement - quality improvement - is strategic planning of quality and use of such instruments as external and internal audit, introduction of common educational standard. Generally, such approach contributes to development of management engineering focused on solution of specific problems of production and technological tasks and engineering corresponding organization structures based on situational principles, methods, and management tools. Critical evaluation of consequences of the technologic approach to education quality management is given in UNESCO's Towards Knowledge Societies report (Towards Knowledge Societies, 2005) that states that assignment of measuring units to knowledge leads to the need for development of "formatized" and standardized knowledge, which would be compatible with measuring units. Speed of cognitive tasks (i.a. that require for reflection) execution becomes a measuring unit. As a consequence, preference is given to short 
statement, that trains the learning to cursory examination of knowledge rather than to its analysis. The Report states that such approach turns "sanctuaries of sciences" into supermarkets trading information or standardized cognitive skills.

Considering education quality a complex characteristic of learner's educational activity and training, expressing the degree of their conformance to educational standards and needs of the person in the interests of whom educational activity is carried out, it should be noted that education quality is defined by its world outlook focus and strengthening of teaching educational functions. Technological effectiveness, projects feasibility, outcomes effectiveness, etc. are important criteria of any practical and modifying activity, if it's considered strictly in a professional way from a perspective of set goal achievement. The future of education directly depends on understanding of knowledge "human quality" preservation problem. Education should be carried out in inseparable unity of teaching and mentoring, that's why it's necessary to understand not only in what way and how to manage education but essence of this process, it's humane meaning. Education management in the knowledge society should have regard to understanding of quality as a sociocultural phenomenon recording not only essential definiteness of an object but its functional and notional significance for human activity, taking into account that not qualities, but values assign meaning to human life. Quality is means for solution of existential problems of human existence, besides, providing that quality as a culturally adapted property objectifies and socializes non-material values and meanings. The culture of the information society doesn't eliminate contradictions between faith and knowledge, religion, science and mysticism, it grows from these contradictions and rises over them. World outlook intolerance of divided humanities under the conditions of information free dissemination gives way to world outlook diversity. It becomes not only spiritual environment, from where the person can choose the acceptable for his inner world formation but the inner dimension of this person. Holistic model of education management "takes away" opposition between technologic and axiological approaches. It's achieved, on the one hand, by means of adherence to existing social and cultural, educational rates-traditions with which one or another ethnocultural community identifies itself, a certain individual related to a certain ethnos carries out self-identification, and, on the other hand, introduction of common (international) standards as corresponding results of the processes of globalization.

\section{Conclusions and Proposals}

Carried out study showed that the information society development at its modern stage called the knowledge society is of contradictory nature related to objective needs of this society development and anthropological risks, which appear in this respect. The most significant needs are need in self-identification, new knowledge and corresponding kinds of creative activity, trust. Realization of these needs gives rise to specific risks: loss of identification and trust, hyperactivity, which are determining for the modern stage of information society development. It should be noted that they are essential manifestations of the information epoch and principally inherent. The study of anthropological risks, nature of its manifestation in the information society allows considering its features when developing strategies of society's risk exposure decrease, decision-making in the area of management in the framework of long-term international, federal, and regional target programs. Thus, the condition of convergent technologies' risks minimization is establishing interdisciplinary methodology with obligatory involvement of humane technologies, which will allow keeping pace with scientific and technological possibilities implementation in our life, carrying out their estimation in due time and, if necessary, developing precautionary measures not only for the human personality but society in general. Philosophical and theoretical analysis of anthropological risks of the information society with the use of empirical material allows stating a number of proposals and recommendations of practical nature, which can be used by organizations/corporations that make decisions in the area of risk management. Among them there are the following: 1) creation of atmosphere of trust is critical for society's risk exposure decrease; 2) creation of comfortable atmosphere providing realization of the principle of trust leads to decrease in hyperactivity risks, which are conditioned by increasing competition in all areas of society and extreme overloads caused by excessive information flows; 3) creation of conditions to preserve identity provides social and psychological person's stability under conditions of rapidly growing innovative changes undermining person's adaptability limit base. The authors conclude that one of important methods for anthropological risks reduction in the information society is introduction of the holistic education management model in the unity of technological and axiological approaches. This introduction is focused on educational activity quality assurance and integral personality formation.

\section{Acknowledgments}

The authors would like to express gratitude to colleagues and friends Kondratyev Viktor Mikhailovich, Malyukova Olga Vladimirovna, Skorodumov Boris Ivanovich for their useful comments and remarks when during working paper. 


\section{References}

Ball, P. (2006). Nanoethics and the purpose of new technologies. Lecture at the Royal Society for Arts. London, March.

Barannikov, V. P., \& Matronina, L. F. (2004). The dynamics of religiosity in information society culture. The journal of "Sotsiologicheskie issledovaniya", pp. 102-107.

Bechmann, G. (2010). Modern society: the risk society, the information society, the knowledge society. Moscow: Logos.

Beck, U. (2009). World at risk. Polity Press, Cambridge.

Bouchard, R. (2003). Biosystemic Syntesis. Science and Technology Foresight Pilot Project, STFPP Research Report. No. 4. Ottava, June.

Brake, D. (2014). Sharing our lives online: risks and exposure in social media. University of Bedfordsire, UK.

Bronzino, J. (2006). The biomedical engineering handbook, third edition. CRC Press.

Fukuyama, F. (2004). Our post-human future: Consequences of biotechnological revolution. Moscow: AST.

Grunwald, A. (2012). Responsible nanobiotechnology: Philosophy and ethics. Pan Stanford Publishing, Singapore.

Gui Gu Tzu. Retrieved from: http://www.vostlit.info/Texts/Dokumenty/China///Guj_Gu_Tsy/text.phtml

Habermas, J. (2002). Future of humanity. Moscow: Ves Mir.

Joffe, H., Rossetto, T., \& Adams, J. (2013). Cities at risk: living with perils in the 21 st. Springer Dordrecht Heidelberg. New York. London.

Johnson, D. G., \& Wetmore, J. M. (Eds.) (2009). Technology and society: Building our sociotechnical future (inside technology). The MIT Press Cambringe, Massachusetts London, England.

Florida, R. (2002). The rise of the creative class. And how it's transforming work, leisure, community and everyday life. Basic Books, New York.

Knight, F. H. (2014) Risk uncertainty and profit. Reprint of 1921. Signalman Publishing. USA.

Kovalchuk, M. V. (2011). Convergence of sciences and technologies - breakthrough into the future. The journal of "Rossiyskie nanotehnologii", Vol. 6, No. 1-2, pp. 13-23.

Kudashov, V. I., \& Omelchenko, N. V. (2014). Global future 2045. Convergent case technologies (BNICS) and transhumanitarian evolution. The journal of "Voprosy filosofii", No. 8, pp. 176-181.

Lektorsky, V. A. (2010). Philosophy, the knowledge society and human prospects. The journal of "Voprosy filosofii", 8, pp. 30-34.

Lewens, T. (Ed.) (2007). Risk: Philosophical Perspectives. Routledge. London and New York.

Matronina, L. F. (2014). Quality of education as an imperative of modernity. The journal of "Filosofiya obrazovanoya", 1, pp. 11-19.

Melikov, I. M., \& Gezalov, A.A. (2012). Dialogue of cultures and culture of dialogue: conceptual frameworks. The journal of "Voprosy filosofii,"12, pp. 24-35.

Mukhopadhyay (2005). Total quality management in education, 2-nd ed. SAGE Publications Pvt. Ltd. London.

Okechukwu, F. Ch. (2011). Total quality management in higher education: Symbolism or substance? A close look at the Nigerian University System. Retrieved from: http://books.google.ru/books?id=IA-48SPgzwC\&printsec=frontcover\&hl=ru\#v= onepage\&q\&f= false

Padhi, N. (2010). Total quality management of distance education. New Delhi: Atlantic Publishers \& Distributors.

Pride, V., \& Korotaev, A. V. (Eds.) (2008). New technologies and continuation of human evolution? Transhumanitarian project of the future. Moscow: LKI.

Renn, O. (2008). Risk Governance: Coping with uncertainty in a complex world (Earthscan Risk in Society). Carthscan. London. Sterling, VA.

Rosa, E., \& McCright, A. (2014). The risk society revisited: Social theory and risk. Governance Temple University Press. Philadelphhia, Pensylvania.

Sallis, E. (2002). Total quality management in education. London: Kogan Page.

Skorodumov, B. I., Skorodumova, O. B. \& Matronina, L. F. (2015). Research of Human Factors in Information Security. Modern Applied Science; Vol. 9, No. 5, May. Special issue. Canadian Center of Science and Education, pp.287-294.

Stock, G. (2003). Redesigning humans. Choosing our genes, changing our future. Mariner Books. Boston, N.Y.

Skorodumova, O. B. (2004). Hackers as a phenomenon of information space. The journal of "Sotsiologicheskie issledovaniya", 2, pp. 70-79.

Skorodumova, O. B., Matronina, L. F., \& Ruchkina, G. F. (2014). Philosophical issues of engineering and informatics. Moscow: UMiNL.

UNESCO. (2005). Towards Knowledge Societies. UNESCO world report. Retrieved from: http://unesdoc.unesco.org/images/0014 1001418/141843e.pdf

Yudin, B. G. (2008). Creation of a transhuman. The journal of the Herald of the Russian Academy of Science", Vol. 77, 6, pp. 520-57.

Yudin, B. G., \& Kapitsa, S. P. (2005). Medicine of the 21st century: ethic problems. The journal of "Znanie.Ponimanie.Umenie", 3, pp. 7579. 
ISSN 2039-2117 (online) ISSN 2039-9340 (print)
Mediterranean Journal of Social Sciences MCSER Publishing, Rome-Italy
Vol 6 No $3 \mathrm{~S} 3$ May 2015 